\title{
Authority of Consumer Dispute Resolution Agency (BPSK) on Calling of Land Agency Makers (PPAT) in Dispute Resolution Through Mediation Outside the Court
}

\author{
Intan Syuhadaa Zain ${ }^{1} \quad$ Sudiarto $^{2} \quad$ Kurniawan $^{2}$ \\ 1.Graduate Program Student in Notary, Faculty of Law, Mataram University, Indonesia \\ 2.Lecturer of Faculty of Law, Mataram University, Indonesia
}

\begin{abstract}
The UUPK gives the authority to BPSK to summon witnesses in his trial. One of them is calling PPAT. Article 50 Permen ATR Number 2 Year 2018 concerning Development and Supervision of PPAT. PPAT called as witnesses can be given legal assistance in the investigation and / or expert testimony in court. The article only regulates legal assistance that can be given to PPAT in dispute resolution in court. There are no other articles that regulate summons or legal assistance for PPAT summons in resolving disputes outside the court. So there is a norm of emptiness. The problem is how is the authority of BPSK to call PPAT as a witness in dispute resolution through mediation outside the court and how is the obligation to keep the authentic PPAT deed confidential on dispute resolution through mediation outside the court. This study aims to analyze the authority of BPSK on the summons of PPAT as a witness in dispute resolution through mediation outside the court and analyze the obligation to keep PPAT authentic deeds confidential on dispute resolution through mediation outside the court. This research method uses normative juridical research methods. The approach used is the Legislative Approach, and Conceptual Approach. The results of this study are: First, the authority of BPSK to call PPAT as a witness in dispute resolution through mediation outside the court is an attribute authority granted by the UUPK as regulated in the provisions of Article 52 of the UUPK. Second, the obligation to keep an authentic PPAT deed in the resolution of disputes outside the court is a relative (relative) obligation, because the nature of the mediation trials outside the court is closed, confidential, consensual, collaborative. So, it does not cause conflicting interests.
\end{abstract}

Keywords: BPSK, Authority, Witness, PPAT

DOI: $10.7176 / \mathrm{JLPG} / 98-06$

Publication date:June 30th 2020

\section{Introduction}

Communities in interacting are very possible and often cause social phenomena in the form of conflicts that arise due to the different interests of the community. ${ }^{1}$ The law has provided a dispute resolution mechanism, especially in civil law, we are faced with two choices for resolving disputes, namely dispute resolution in court (litigation) and settlement of litigation outside the court (non-litigation). In general, the community often resolves disputes with parties another by filing a lawsuit in court (litigation). Even if the litigation dispute is finally resolved, the settlement is merely a last resort (ultimatum remedium) after other alternatives are considered to be fruitless. ${ }^{2}$

The term alternative dispute resolution (ADR) or dispute resolution outside the court in Indonesia is relatively new, but in fact consensus dispute resolution has long been carried out by the community, which basically emphasizes the efforts of consensus, family, peace, and so on. ${ }^{3}$ The concept of alternative dispute resolution (ADR) was crystallized in Indonesian law with the issuance of Law Number 30 of 1999 concerning Arbitration and Alternative Dispute Resolution. ${ }^{4}$ Other ways of resolving disputes outside the court, can be in the form of arbitration or some other alternative dispute resolution, such as consultation, negotiation, mediation, or conciliation. $^{5}$

Law Number 8 of 1999 concerning Consumer Protection authorizes the Consumer Dispute Settlement Agency (BPSK) to carry out several functions in dispute resolution, namely the arbitration and mediation functions as referred to in Article 52 which states that one of the tasks and authority of the Dispute Resolution Board Consumers, namely the handling and resolution of consumer disputes through mediation or arbitration or conciliation. Thus, it can be said, that BPSK is an institution that carries out mediation functions.

In the process of resolving disputes by means of mediation, BPSK has the authority to summon and present witnesses, expert witnesses, or any person deemed aware of violations of the Consumer Protection Act. One of

\footnotetext{
${ }^{1}$ Nurnaningsih Amriani, Mediasi Alternatif Penyelesaian Sengketa Perdata di Pengadilan, PT.Raja Grafindo Persada, 2012, Jakarta, halaman

${ }^{2}$ Budiman N.P.D Sinaga,Hukum Kontrak dan Penyelesaian Sengketa Dari Perspektif Sekretaris, Raja Grafindo Persada, Jakarta, 2005, halaman 39

${ }^{3}$ Sophar Maru Hutagalung, Praktik Peradilan Perdata dan Alternatif Penyelesaian Sengketa, Sinar Grafika, Jakarta, 2014 , halaman 311

${ }^{4}$ Sudiarto, Negosiasi, Mediasi, dan Arbitrase: Penyelesaian Sengketa Alternatif Di Indonesia, Pustaka Reka Cipta, Bandung, 2013, halaman 2

${ }^{5}$ Budiman N.P.D Sinaga, Op.cit.,halaman 49
} 
them is the Acting Maker of Land Deed (hereinafter referred to as PPAT).

The existence of PPAT as a witness, if related to the existence of his position in the legal field, has the role of supporting the smooth running of a legal process. Based on the provisions in Article 50 of the Regulation of the Minister of Agrarian Affairs and Spatial Planning / Head of the National Land Agency of the Republic of Indonesia Number 2 of 2018 concerning Development and Supervision of PPAT, which states that:

(1) The Ministry, the Board of Trustees and Supervisors of PPAT and / or IPPAT can provide legal assistance to PPAT who are called as witnesses or suspects by investigators.

(2) PPAT summoned as witnesses or suspects by investigators can apply for legal assistance.

(3) Legal assistance as referred to in paragraph (1) can be in the form of advice, input / assistance in investigations and / or expert statements in court.

(4) The Ministry, the Board of Trustees and Supervisors of PPAT and / or IPPAT may form a joint team to provide legal assistance to PPAT whose members come from elements of the Ministry, Board of Trustees and Supervisors of PPAT and / or IPPAT.

(5) In the event that the investigator will examine the PPAT on suspicion of a criminal offense may coordinate with the Ministry, the Board of Trustees and Supervisors of PPAT and / or IPPAT.

Provisions of Article 50 of the Regulation of the Minister of Agrarian Affairs and Spatial Planning / Head of the National Land Agency of the Republic of Indonesia Number 2 of 2018 concerning Development and Supervision of the PPAT only regulates legal assistance related to calling PPAT as witnesses or suspects in the process of resolving disputes in court alone, cannot found articles in the legislation related to other PPAT positions that explicitly regulate both the legal assistance and mechanism for calling PPAT as witnesses in resolving disputes outside the court. Does the summons require permission or approval from the competent institution or organization such as notary summons and examination, which is based on the provisions in Article 66 paragraph (1) of Law Number 2 of 2014 concerning Amendments to Law Number 30 of 2004 concerning Notary Position states that for the benefit of the judicial process, investigators, public prosecutors, and judges with the approval of the Notary Honorary Council are authorized to take a photocopy of the minutes of the deed as well as the summons and examination of the Notary Public. So that it creates a legal vacuum.

In the aspect of law enforcement, the obligation to fulfill the summons as a witness is generally affirmed in Article 224 of the Criminal Code and Article 522 of the Criminal Code with due regard to the provisions affirmed in Article 322 paragraph (1) of the Criminal Code by law enforcement when PPAT is called as a witness at a trial. On the other hand, PPAT as a public official who is given the authority along with the obligations in making the deed, must be able to guarantee certainty, legal protection between the parties, including matters entrusted to him to be kept confidential based on the oath of office he uttered as regulated in Article 34 of the Regulation of the Head of the Land Agency National (hereinafter referred to as PERKABAN) Number 1 of 2006 concerning the provisions of the Implementation of Government Regulation Number 37 of 1998 concerning PPAT Position Regulations, which states: "That I (PPAT), will keep the contents of the deeds made before me and the protocol that is the responsibility I, who according to his nature or legislation must be kept confidential ". The contents of the deed must be kept confidential and become the responsibility of the PPAT, where the violation may be subject to sanctions based on the provisions in Article 322 paragraph (1) of the Criminal Code which states that whoever intentionally discloses something secret, which he is obliged to keep, because of his position or occupation, whether that sekerang or formerly, convicted with imprisonment for a maximum of 9 (nine) months. Therefore, it is necessary to study the obligation to keep an authentic deed made by the PPAT in resolving disputes outside the court, bearing in mind that one of the objectives of resolving disputes outside the court is to obtain a win-win solution.

\section{Research methods}

This type of research used in this study is normative juridical research by making field data as a support. As for the approach used in this study is the Legislative Approach (Statue Approach) and Conceptual Approach (Conceptual Approach). The legal materials used in this study are primary legal materials that are binding legal materials, and consist of statutory regulations, secondary legal materials, namely library materials that contain information about primary legal materials, tertiary legal materials, ${ }^{1}$ namely materials that provide instructions or explanation of primary and secondary legal materials which include legal dictionaries and Indonesian language dictionaries. Collecting and tracing techniques used in this research are literature study techniques on legal materials, both primary legal materials, secondary legal materials, tertiary legal materials or non-legal materials, which are the single methods used in normative research, ${ }^{2}$ where legal materials the literature is inventoried by means of classifying the reading materials sourced from legislation, books or literature, legal dictionaries, documents, and then selected by taking legal material that is relevant to the material discussed. this is analyzed by

\footnotetext{
${ }^{1}$ Bambang Waluyo, Penelitian Hukum Dalam Praktek, Cetakan ke-3, Sinar Grafika,Jakarta,2002,halaman 51

${ }^{2}$ Ibid., halaman 50
} 
describing descriptively, then it is analyzed using an extensive interpretation instrument or analogy thinking method. To gain an understanding of the problems that occur, a deductive method of drawing conclusions is used which is drawing conclusions from things that are general to matters Thing which is special.

\section{Results and discussion}

3.1 The Authority of the Consumer Dispute Resolution Board (BPSK) Against Summoning PPAT as a Witness in Settlement of Disputes through Mediation Outside the Court

3.1.1 History of Co-Administration of BPSK

The establishment of BPSK in each Regency / City is based on the provisions in Article 49 paragraph (1) of the Consumer Protection Act which essentially determines the establishment of the Consumer Dispute Settlement Body (BPSK) only in the Second Level Regions (districts / cities), which are then confirmed by the existence of Decree of the President of the Republic of Indonesia, namely in the first stage 10 (ten) Consumer Dispute Settlement Bodies were formed based on Presidential Decree No. 90/2001 concerning the Establishment of Consumer Dispute Resolution Board for the City of Medan, Palembang City, Central Jakarta City, West Jakarta City, Kota Bandung, Semarang City, Yogyakarta City, Surabaya City, Malang City and Makassar City.

Following up on the establishment of BPSK, a Decree of the Minister of Industry and Trade No. 350 / MPP / Kep / 12/2001 was issued concerning the Implementation of Tasks and Powers of BPSK, which is the procedural law for BPSK in carrying out its task of resolving disputes between consumers and business actors. formed since the formation of BPSK in 2001 until 2019 in Regencies / Cities in Indonesia as many as 185 (one hundred eightyfive) BPSK, with the information that there are several BPSK that are active, less active, not yet inaugurated, and demisioner.

The problem related to the establishment of BPSK is the impact of the enactment of Law Number 22 of 1999 concerning the authority of the central government over these institutions. One problem that arises is that the UUPK regulates that the establishment of BPSK is an initiative from the central government. This authority is not in line with the spirit of regional autonomy, so that in practice it is no longer the central government who took the initiative but the district / city government.

The issuance of Law No. 23 of 2014 concerning Regional Government has regulated that the division of government affairs in the field of trade in general sub standardization and consumer protection is the province's authority, in this case including the existence of the Consumer Dispute Resolution Board (BPSK). Thus BPSK, which was originally the authority of the district / city government, has now become the authority of the provincial government (the authority in question is the authority to finance the implementation and the recruitment authority of BPSK members).

The authority to finance the implementation of the BPSK was strengthened by Regulation of the Minister of Trade of the Republic of Indonesia Number 06 / M-DAG / PER / 2/2017 Regarding the Consumer Dispute Resolution Board, which stipulates that the cost of conducting BPSK is charged to the provincial Regional Budget (APBD) according to ability regional finance. For this reason, all costs incurred in carrying out the duties and functions of BPSK are fully borne by the finance of the provincial government.

The establishment of the BPSK institution, the resolution of consumer disputes can be done quickly, easily, and cheaply. It is fast because the dispute resolution through BPSK must be resolved within 21 working days, and no appeal is possible as long as the settlement is done by mediation and conciliation. Easy because the administrative procedures and decision making process are very simple, and can be done by the parties themselves without the need for legal counsel. cheap because the trial fee is free of charge. ${ }^{1}$

3.1.2 Definition of Authority

Authority or authority is a term commonly used in the field of public law. Basically there are differences between the two. ${ }^{2}$ Att Syafrudin argues that authority (authority, gezag) is what is called formal power, power that comes from the power given by the law, whereas authority (competence bevoegheid) is only about an "onderdeel" (part ) certain of the authority. ${ }^{3}$

According to P. Nicolai in his authority there are rights and obligations that must be carried out. authority is the ability to carry out certain legal actions (ie actions intended to have legal consequences, and involve the emergence and disappearance of legal consequences). Rights contain the freedom to do or not do certain actions, while the obligation includes the obligation to do or not do certain actions. Within the authority there are authorities (rechtsbe voegdheden). ${ }^{4}$

Authority is the scope of public legal action, the scope of governmental authority, not only includes authority

\footnotetext{
${ }^{1}$ Susanti Adi Nugroho, Proses Penyelesaian Sengketa Konsumen Ditinjau dari Hukum Acara Serta Kendala Implementasinya, Kencana Prenada Media Group, Jakarta, 2008, halaman 75

${ }^{2}$ Sarkawi, Hukum Administrasi Negara, Cetakan Kedua, Pustaka Bangsa, Mataram, 2014, halaman 152

${ }^{3}$ Ibid.,

${ }^{4}$ P. Nicolai dalam Juniarso Ridwan dan Achmad Sodik Sudrajat, Hukum Administrasi Negara dan Kebijakan Pelayanan Publik, Nuansa, Bandung, 2010, halaman 136
} 
to make government decisions (bestuur), but includes authority in the context of carrying out tasks, and giving authority and distribution of its main authority stipulated in legislation. According to Herbert A. Simons, ${ }^{1}$ authority is a power to make decisions and relates to the relationship between the supervisor and leader According to Bagir Manan as quoted by Sarkawi, stated that authority in legal language is not the same as power (macht). Power only reflects the right to do or not do. In law, authority also means rights and obligations (rehten en plichten). ${ }^{2}$ An authority contains rights and obligations. There is no authority without rights. Authority without rights is only a collection of obligations. Conversely there is no authority without obligation. Authority without obligation will be a mere collection of rights and this can easily lead to arbitrariness. ${ }^{3}$

The concept of authority that is the author's reference in analyzing the problems in this paper is the concept or understanding of authority put forward by Bagir Manan and P. Nicolai, who state that there are rights, obligations and obligations in authority. With the authority given to BPSK, the rights and obligations arising from it arise. But without authority, rights and obligations will not be granted to him.

3.1.3 Authority of the Consumer Dispute Settlement Agency (BPSK) Against Summoning PPAT as a Witness in Settlement of Disputes through Mediation Outside the Court

Law Number 8 of 1999 concerning Consumer Protection authorizes the Consumer Dispute Settlement Agency (BPSK) to carry out several functions in dispute resolution, namely the arbitration and mediation functions as referred to in Article 52 which states that one of the tasks and authority of the Dispute Resolution Board Consumers, namely the handling and resolution of consumer disputes through mediation or arbitration or conciliation. Thus it can be said, that BPSK is an institution that carries out mediation functions. Dispute resolution through mediation sometimes ends in a deadlock (deadlock, stalemate). In such case by the Assembly and / or at the suggestion or request of the parties to the dispute it can be presented, such as a dispute in the Consumer Dispute Resolution Board (BPSK) of the City of Mataram in the West Nusa Tenggara Province in case Number 01 / BPSK / I / 2012 between Fika Wulandari and PT. NTB Prima Housing, which also presented the West Lombok National Land Agency, the Chairman of PT. Bank NTB Main Branch Pejanggik, and a PPAT domiciled in West Lombok to be present as a witness in dispute resolution through mediation at BPSK.

Provisions of Article 50 of the Regulation of the Minister of Agrarian Affairs and Spatial Planning / Head of the National Land Agency of the Republic of Indonesia Number 2 of 2018 concerning Development and Supervision of the PPAT only regulates legal assistance related to the invitation of PPAT as witnesses or the suspect in the dispute resolution process in court alone, can not be found articles in the legislation related to other PPAT positions that explicitly regulate both legal assistance and the mechanism for calling PPAT as witnesses in settling disputes outside the court. Based on the results of an interview with Mr. Lalu Irsan Sobari, S.ST as the Section Head of Maintenance of Data on Land Rights and Development of PPAT who is also a member of the Board of Trustees and Supervisors of West Nusa Tenggara Region PPAT said that the provisions in Article 50 of the Minister of Agrarian and Spatial Planning / Head The National Land Agency Number 2 of 2018 cannot be applied to summons to PPAT in the process of resolving disputes outside the court, as long as the summons of PPAT referred to in their capacity as witnesses. However, the PPAT concerned has the obligation to report its summons to professional organizations, in this case the Association of Land Deed Makers (hereinafter referred to as IPPAT) to first hear its statement regarding the reason for his summons as a witness in a dispute resolution outside the court. ${ }^{4}$ Irsan Sobari added that if the mediation process arises there is a possibility that the mediation results at BPSK could not be reached by an agreement, which resulted in the issuance of a recommendation from BPSK to the Police (in the event that a criminal element should be suspected in a dispute). To enable the summon of PPAT by investigators, the provisions in Article 50 can be applied and the PPAT concerned has the right to obtain assistance and legal assistance by the Regional PPAT Board of Trustees and Supervisors. In such case, the summons of PPAT by the investigator must be in writing and signed by the investigator, where the summons must also clearly state the reason for the summons, the status of the summons as a witness or suspect, the time and place and its implementation.

Meanwhile, the provisions regarding the authority of BPSK to summon and present witnesses are regulated in Article 52 letter h of the UUPK jo. Article 3 letter h Decree of the Minister of Industry and Trade No. 350 / MPP / Kep / 12/2001 concerning Implementation of Duties and Authorities of BPSK which states that BPSK has the authority to summon and present witnesses, expert witnesses and / or anyone deemed aware of violations of the UUPK. Based on the results of interviews with Mr. R. Wisnu Haryo Samudro ${ }^{5}$ as Head of Sub Directorate

\footnotetext{
${ }^{1}$ Sarkawi, Op.Cit.,, halaman 154

${ }^{2}$ Bagir Manan dalam Sarkawi, Ibid., halaman 151

${ }^{3}$ Sjachran Basah dalam Sarkawi, Ibid, halaman 156

${ }^{4}$ Wawancara dengan Bapak Lalu Irsan Sobari, S.ST, sebagai Kepala Seksi Pemeliharaan Data Hak Atas Tanah dan Pembinaan PPAT sekaligus Anggota Majelis Pembina dan Pengawas PPAT Wilayah Nusa Tenggara Barat, pada tanggal 27 Maret 2020, di Kantor Wilayah Badan Pertanahan Nasional Nusa Tenggara Barat.

${ }^{5}$ Wawancara dengan Bapak R. Wisnu Haryo Samudro, sebagai Kepala Sub Direktorat Analisa Kasus Perlindungan Konsumen dan Bimbingan Operasional PPBJ dan Penyidik Pegawai Negeri Sipil Perlindungan Konsumen (PPNS-PK), Kementerian Perdagangan, pada tanggal 20 April 2020, melalui telepon seluler.
} 
Analysis of Consumer Protection Cases and PPBJ Operational Guidance and Civil Servant Investigation for Consumer Protection (PPNS-PK), the Ministry of Trade explained that BPSK's authority in the provisions of Article 52 letters $\mathrm{h}$ and $\mathrm{j}$ are related by calling and presenting witnesses, expert witnesses and the authority of BPSK to obtain / assess letters, documents or other evidence for the purposes of examination and investigation, can still be carried out, including the summoning of a Notary and PPAT as witnesses at the hearing at BPSK as well as cases that have been resolved in BPSK Regency of Batu Bara who presents a Notary and also a case in BPSK Mataram City that presents a PPAT as a witness. R. Wisnu Haryo Samudro added that although there were no provisions in the legislation regarding consumer protection that specifically regulates the procedures and guidelines that BPSK must carry out for the summoning of a Notary and PPAT as witnesses, BPSK can still carry out the duties and authority given the law through the provisions in Article 52 of the UUPK by taking into account other laws and regulations such as the Law of Notary Position and other regulations concerning PPAT.

3.2 Obligations of Land Deed Making Officials to Keep Authentic Deed in the Dispute Settlement Out of Court 3.2.1 Land Deed Making Officer

Land Deed Making Official (PPAT) is a public official who is appointed and dismissed by the Head of the Land Agency of the Republic of Indonesia who is authorized to make certain legal actions. ${ }^{1}$ The main task of PPAT is to carry out part of land registration activities by making a deed as proof of certain legal actions regarding land rights or ownership rights of the Flats, which will be the basis for registering changes and land registrations resulting from the legal act. the law includes: a. Buy and sell; b. Exchange; c. Grant; $d$. Entering into the company (inbreng); e. Sharing of joint rights; f. Granting building use rights / use rights on private property rights; g. Granting mortgage rights; and h. The granting of authority imposes mortgage rights. To carry out the main tasks as mentioned above, the PPAT has the authority to make an authentic deed concerning legal acts as referred to above regarding land rights and Ownership Rights in Flats in the working area. Working areas for PPAT, Special PPAT, and Provisional PPAT have been regulated in Article 12 of Government Regulation Number 24 of 2016 , namely:

(1) The PPAT work area is a province;

(2) Temporary PPAT and Special PPAT work areas cover the work area as a government official who becomes the basis for their appointment;

(3) Further provisions regarding the work area of PPAT are regulated by Ministerial regulation.

PPAT rights are regulated in Article 36 of the Head of National Land Agency Regulation No. 1 of 2006 concerning the provisions of the Implementation of Government Regulation Number 37 of 1998 concerning PPAT Position Regulations while the PPAT obligations have been specified in Article 45 of the Head of National Land Agency Regulation Number 1 of 2006 concerning the provisions of the Implementation of Government Regulations Number 37 of 1998 concerning PPAT Position Regulations. Appointment of PPAT is regulated in Article 5 of Government Regulation Number 37 of 1998, while termination of position as PPAT is regulated in Article 8 of Government Regulation Number of Government Regulation Number 24 of 2016.

According to Salim HS, the PPAT deed is: ${ }^{2}$

"Proof of evidence, made in front of and before the PPAT, which contains clauses or rules relating to the rights and obligations of the parties, where the first party is obliged to surrender land rights and / or ownership rights to the unit flats, and the Second Party is obliged to surrender money and receive land titles and / or property rights on the unit flats. "

The PPAT deed has a very important meaning in the transaction on land rights and / or ownership rights on the unit of flats, because it has uses or benefits as evidence. There are two functions of the PPAT deed, namely:

a. Evidence of certain legal actions regarding land rights and ownership rights over flats;

b. A strong basis is made for registering the transfer of rights and the assignment of the rights concerned.

3.2.2 Obligations of Land Deed Makers Officials to Keep Authentic Deeds Under Confidential Dispute Out of Court

The existence of the PPAT position as a witness in the field of law plays a role in supporting the smooth running of a legal process. Pursuant to Article 34 of the Regulation of the Head of the National Land Agency (hereinafter referred to as PERKABAN) Number 1 of 2006 concerning the provisions of the Implementation of Government Regulation Number 37 of 1998 concerning PPAT Position Regulations regarding oath promises of positions as the Actor of Land Drafting Maker requires PPAT to keep the contents of the deeds made before him and the protocol for which it is responsible, which by nature or by law must be kept confidential. On the other hand in the aspect of law enforcement, the obligation to fulfill the summons as a witness is generally affirmed in Article 224 of the Criminal Code and Article 522 of the Criminal Code with due regard to the provisions affirmed in Article 322 paragraph (1) of the Criminal Code by law enforcement when PPAT is called as a witness at a trial. Therefore, the

\footnotetext{
${ }^{1}$ Urip Santoso, Pejabat Pembuat Akta Tanah, Kencana, Jakarta, 2016, halaman 61

${ }^{2}$ Salim HS, Teknik Pembuatan Akta Pejabat Pembuat Akta Tanah (PPAT),Raja Grafindo Persada, Jakarta, 2016, halaman 68-69
} 
PPAT must stand on the interests of the state which refers to the public interest in order to complete the legal process in the court. A PPAT called as a witness can use the right of denial or the right to resign as a witness. Leaking secrets related to the law can be based on Article 322 of the Criminal Code and Article 1909 of the Civil Code and even if there is an element of defamation, it can be seen in the articles of acts against the law in the Civil Code. The purpose of keeping office secrets in terms of public law is to protect the public interest, not to protect the interests of the individual officials concerned. The main goal of keeping a secret position, solely to protect the interests or public order. Not to protect the interests of individual officials. If so, it is not legal and is not justified by law an official exercising the right to resign as a witness must be upheld based on the following considerations: ${ }^{1}$ 1. To what extent is the public interest protected if the official uses the right to resign as a witness; or

2. How big is the danger that threatens the public interest, if the official becomes a witness.

In order to avoid or overcome the misuse of official position as a reason to free fulfill obligations as witnesses, there are those who argue that the absolute secret theory understood so far needs to be shifted. Because the teaching of absolute secrets, has led to glorify the secret function of one's position in totality. Notaries, doctors, lawyers, PBN officials, Bank Officers, and so on cannot be touched by the law anymore. All are reluctant or refuse to become witnesses by using the obligation to keep total office secrets. Whereas sometimes their statements as witnesses are very urgent and relevant in realizing dispute resolution based on truth, especially in dispute resolution through mediation outside the court, which generally ADR provides a potential solution to resolve the problem better than doing it with the procedures already available, such as litigation procedures and other procedures involving decision aides from third parties. ADR procedures can provide the same level of confidentiality guarantee for each party involved and the parties involved have more control over the dispute and predict the results of the dispute. ${ }^{2}$ So that the delivery of information by PPAT in the resolution of disputes through mediation in this court can still be protected. Even in the mediation process, the evidentiary aspect can be set aside for other interests, ${ }^{3}$ because it is consensual or consensus and collaborative in nature, mediation can produce a win-win solution without conflicting interests.

Especially if it is related to the demands of transparency or full transparency voiced by democratic society and globalization, there is enough reason to shift absolute secrets towards an atmosphere of openness. ${ }^{4}$ In fact there is truth in the opinion that states, in a certain atmosphere, speak openly or provide clear information about a matter or legal event, far more important for the protection of the public interest than it is covered up and kept secret. The enforcement of the obligation to keep office secrets absolutely as understood and desired by some parties is sometimes far more dangerous to the public interest if the official resigns as a witness. So it is necessary to avoid obscuring the secret of the position itself, because notaries, public accountants, estimators, PPAT, and other positions are very valuable to act as witnesses in a particular case both in the process of dispute resolution in court and the resolution of disputes outside the court.

\section{Conclusion}

1. The UUPK authorizes the Consumer Dispute Settlement Agency (BPSK) to carry out several functions in dispute resolution, namely the arbitration and mediation functions as referred to in Article 52 letter a which states that one of the tasks and authority of BPSK is to carry out the handling and resolution of consumer disputes through mediation or arbitration or conciliation. As an institution that carries out mediation functions outside the court, BPSK is also given attributive authority based on Article 52 of the UUPK to summon and present witnesses or to obtain / evaluate letters, documents or other evidence for the purposes of examination, and investigation, including calling a PPAT as a witness to the trial at BPSK. Although there are no provisions in the legislation regarding consumer protection that specifically regulates the procedures and guidelines that BPSK has to do with calling a PPAT as a witness, BPSK can still carry out the duties and authority granted by the UUPK through the provisions in Article 52 letter $\mathrm{h}$ and $\mathrm{j}$, with due regard to other laws and regulations such as the Law of Notary Position and other regulations concerning PPAT.

2. The obligation to keep an authentic deed of PPAT on a dispute resolution outside the court of law is a relative (relative) obligation. This is because the nature of the mediation trials outside the court is generally held in private and confidential, unless the parties allow the mediation that they are taking to be open to the public. So that the delivery of information by PPAT in the resolution of disputes through mediation in this court can still be protected. Even in the mediation process, the evidentiary aspect can be set aside for other interests, because it is consensual or consensus and collaborative in nature, mediation can produce a win-win solution without conflicting interests.

\footnotetext{
${ }^{1}$ M.Yahya Harahap, Hukum Acara Perdata (Gugatan, persidangan, Penyitaan, Pembuktian, dan Putusan Pengadilan), Sinar Grafika, Jakarta, 2005, halaman 669

${ }^{2}$ Nurnaningsih Amriani, Op.Cit., halaman 49

${ }^{3}$ Takdir Rahmadi, Mediasi Penyelesaian Sengketa Melalui Pendekatan Mufakat, PT. Raja Grafindo Persada, Jakarta, 2010, halaman 24

${ }^{4}$ M. Yahya Harahap, Op.Cit., halaman 670
} 


\section{REFFERENCES}

Bambang Waluyo, 2002, Penelitian Hukum Dalam Praktek, Cetakan ke-3, Sinar Grafika,Jakarta.

Budiman N.P.D Sinaga, 2005, Hukum Kontrak dan Penyelesaian Sengketa Dari Perspektif Sekretaris, Raja Grafindo Persada, Jakarta.

M.Yahya Harahap, 2005, Hukum Acara Perdata (Gugatan, persidangan, Penyitaan, Pembuktian, dan Putusan Pengadilan), Sinar Grafika, Jakarta.

Nurnaningsih Amriani, 2012, Mediasi Alternatif Penyelesaian Sengketa Perdata di Pengadilan, PT.Raja Grafindo Persada, Jakarta.

Salim HS , 2016,Teknik Pembuatan Akta Pejabat Pembuat Akta Tanah (PPAT),Raja Grafindo Persada, Jakarta

Sarkawi, 2014, Hukum Administrasi Negara, Cetakan Kedua, Pustaka Bangsa, Mataram.

Sophar Maru Hutagalung, 2014, Praktik Peradilan Perdata dan Alternatif Penyelesaian Sengketa, Sinar Grafika, Jakarta.

Sudiarto, 2013, Negosiasi, Mediasi, dan Arbitrase: Penyelesaian Sengketa Alternatif Di Indonesia, Pustaka Reka Cipta, Bandung.

Susanti Adi Nugroho, Proses Penyelesaian Sengketa Konsumen Ditinjau dari Hukum Acara Serta Kendala Implementasinya, Kencana Prenada Media Group, Jakarta, 2008

Takdir Rahmadi, 2010, Mediasi Penyelesaian Sengketa Melalui Pendekatan Mufakat, PT. Raja Grafindo Persada, Jakarta.

P. Nicolai dalam Juniarso Ridwan dan Achmad Sodik Sudrajat, 2010, Hukum Administrasi Negara dan Kebijakan Pelayanan Publik, Nuansa, Bandung.

Urip Santoso, 2016, Pejabat Pembuat Akta Tanah, Kencana, Jakarta.

Indonesia, Undang-Undang Republik Indonesia Nomor 8 Tahun 1999 tentang Perlindungan Konsumen, (Lembaran Negara Republik Indonesia Tahun 1999 Nomor 42, Tambahan Lembaran Negara Republik Indonesia Nomor 3821)

Indonesia, Peraturan Pemerintah Republik Indonesia Nomor 37 Tahun 1998 tentang Peraturan Jabatan Pejabat Pembuat Akta Tanah, (Lembaran Negara Republik Indonesia Tahun 1998 Nomor 52, Tambahan Lembaran Negara Republik Indonesia Nomor 3746)

Indonesia, Peraturan Pemerintah Republik Indonesia Nomor 24 Tahun 2016 tentang Perubahan Atas Peraturan Pemerintah Republik Indonesia Nomor 37 Tahun 1998 tentang Peraturan Jabatan Pejabat Pembuat Akta Tanah, (Lembaran Negara Republik Indonesia Tahun 2016 Nomor 120, Tambahan Lembaran Negara Republik Indonesia Nomor 5893)

Indonesia, Peraturan Menteri Agraria dan Tata Ruang/Kepala Badan Pertanahan Nasional Republik Indonesia Nomor 2 Tahun 2018 tentang Pembinaan dan Pengawasan Pejabat Pembuat Akta Tanah, (Berita Negara Republik Indonesia Tahun 2018 Nomor 395)

Indonesia, Keputusan Menteri Perindustrian dan Perdagangan Nomor 350/MPP/KEP/12/2001 tentang Pelaksanaan Tugas dan Wewenang Badan Penyelesaian Sengketa Konsumen.

Indonesia, Peraturan Kepala Badan Pertanahan Nasional Nomor 1 Tahun 2006 tentang Ketentuan Pelaksanaan Peraturan Pemerintah Nomor 37 Tahun 1998 tentang Peraturan Jabatan Pejabat Pembuat Akta Tanah. 